\title{
ANALISIS BATASAN PEREDARAN BRUTO USAHA ATAS PELAKSANAAN PERATURAN PEMERINTAH NOMOR 46 TAHUN 2013
}

\author{
R. Soerjatno* \\ soerjatno.rd @gmail.com
}

\section{Abstract}

The policy on the enactment of Government Regulation No. 46 of 2013 is based on the consideration to facilitate taxpayers in calculating the tax so that more taxpayers are expected to register as taxpayers because of the ease in calculating the tax.Government Regulation No. 46 of 2013 is applied to Taxpayers having gross turnover up to Rp.4.800.000.000,00 a year and not applicable to those who have income from free employment (doctors, notaries etc.). PP46 tariff is 1\% of Gross business turnover so that any Brule Distribution will be subject to Income Tax of 1\% of Gross Distribution. However, in Law No.7 of 1983 as amended by Act no.36 of 2008 in Article 17 paragraph (1) in the explanation states that Tax Payable Individual Taxpayer is Tariff Psl.17 Income Tax Law multiplied by Income Taxable Tax, while based on Article 16 paragraph (2) of Income Tax Law, Taxable Income for WP Person is Net Income minus Non Taxable Income.Based on the calculation difference, the authors conducted the study in order that the implementation of tax rules remains procedural and easy but still has a sense of justice especially for small Taxpayers .

Keywords: government Regulation No.46 of 2013, income tax.

\section{Pendahuluan}

Pajak mempunyai kontribusi yang cukup tinggi dalam penerimaan negara. Pada lima tahun terakhir ini, penerimaan pajak dapat mencapai lebih dari $70 \%$ dari total penerimaan negara yang dilaporkan dalam Anggaran Pendapatan dan Belanja Negara (APBN). Untuk membangun Negara pasti dilakukan dana berupa uang yang digali dari seluruh potensi yang ada di negara ini. Menurut (Suandy;2011:2), sumber-sumber penerimaan negara dapat dikelompokkan menjadi penerimaan dari beberapa sektor, sebagai berikut:
1. Pajak;
2. Kekayaan Alam;

* Dosen Program Studi D3 Perpajakan Politeknik Ubaya, Surabaya 

3. Bea dan Cukai;
4. Retribusi;
5. Iuran;
6. Sumbangan;
7. Laba dari badan usaha milik negara;
8. Sumber-sumber lain.

Sumber keuangan negara yang berasal dari rakyat melalui pungutan pajak dan/ atau dari natural resourches (hasil kekayaan alam) yang terdapat didalam negara tersebut merupakan sumber keuangan yang paling aman posisinya bila dibandingkan dengan sumber keuangan negara yang berasal dari pinjaman luar negeri (Irianto;2009:62). Berdasarkan Undang-Undang Nomor 6 tahun 1983 sebagaimana telah diubah dengan Undang-Undang Nomor 16 tahun 2009 tentang Ketentuan Umum dan Tatacara Perpajakan, pada Pasal 1 angka 1 dinyatakan bahwa Pajak adalah kontribusi wajib kepada negara yang terutang oleh orang pribadi atau badan yang bersifat memaksa berdasarkan undang-undang, dengan tidak mendapatkan imbalan secara langsung dan digunakan untuk keperluan negara bagi sebesar-besarnya kemakmuran rakyat.

Dari definisi tersebut berarti bahwa Pemerintah dapat memungut pajak kepada masyarakat Indonesia namun harus berdasarkan Undang-Undang artinya aturannya harus disetujui oleh Dewan Perwakilan Rakyat (DPR) sehingga dapat dipastikan bahwa pungutan pajak didasarkan pada keadilan karena seluruh aturan dalam memungut pajak yang dilakukan oleh pemerintah harus berdasarkan UndangUndang ini ditandai karena telah disetujui oleh wakil-wakil rakyat. Walaupun setelah pemungutan pajak Pemerintah tidak memberikan imbalan tertentu kepada pembayar pajak, namun menurut Menteri Perindustrian (2006;8-9), pajak bisa menjadi insentif. Instrumen pajak bisa berfungsi menjadi insentif bagi dunia usaha/industri yang mempunyai prioritas tinggi dalam pembangunan ekonomi nasional dan untuk menarik investasi dari negara lain.

Dengan demikian, uang pajak yang dikumpulkan dapat langsung dimanfaatkan bagi pemberian insentif sebagai pembayar pajak guna menarik investasi yang lebih besar. Insentif pajak dapat diberikan untuk kegiatan, antara lain pengembangan investasi, pengembangan industri pioner, pengembangan industri tertentu dan strategis, pengembangan daerah tertinggal yang minim sarana dan prasarana, dan pengembangan industri kecil dan menengah (IKM) (Irianto: 2009:67) Seiring dengan kebijakan pembangunan yang terus menerus demi mewujudkan kesejahteraan rakyat, maka pemerintah berupaya terus melakukan peningkatan penerimaan negara dari sektor pajak.

Pada dua tahun terakhir ini Pemerintah mampu merealisasikan penerimaan pajak senilai Rp.1.055 Triliun pada tahun 2015 kemarin, jumlah tersebut mencapai 81,5 persen dariyang ditargetkan dalam Anggaran Pendapatan dan Belanja Negara Perubahan (APBNP) 2015 yang tercatat Rp.1.294,25 triliun (Liputan6.com). Sedangkan realisasi penerimaan tahun 2016 adalah Rp.1.105 triliun dan untuk Tahun 2017 Pemerintah sendiri mematok target penerimaan pajak dalam Anggaran Pendapatan dan Belanja Negara (APBN) 2017 sebesar Rp.1.307,9 triliun (Kompas.com). Dari data tersebut dapat kita lihat betapa tingginya jumlah yang harus diperoleh dari sektor pajak. Sebagai ilustrasi kenaikan penerimaan pajak dapat kita hitung bahwa penerimaan pajak tahun 2016 meningkat sebesar 4,74\% dibanding penerimaan pajak tahun 2015. Jika kita bandingkan dengan inflasi dan pertumbuhan usaha, maka kenaikan sebesar 4,74\% tersebut dirasa masih kurang. Namun banyak faktor yang mempengaruhi kecilnya peningkatan penerimaan pajak antara lain adalah perkembangan ekonomi yang 
melemah baik secara Internasional maupun Nasional.

Jika kondisi ekonomi yang kurang bergairah sudahbarangtentumengakibatkan omzet perusahaan akan berkurang dan mengakibatkan keuntungan perusahaan menjadi mengecil. Karena pengenaan pajak didasarkan pada omzet atau keuntungan perusahaan maka akibatnya pajak akan menjadi kecil juga. Efek dari penerimaan pajak yang berkurang akan mengakibatkan suatu lingkaran yang merugikan semua pihak. Misalnya demikian: Jika keuntungan perusahaan berkurang, sudah dapat dipastikan bahwa belanja perusahaan pun akan dilakukan efisiensi, sedangkan bagi Pemerintah dengan kecilnya penerimaan pajak akan mengakibatkan adanya pengurangan terhadap beberapa program pembangunan misalnya pembangunan infrastruktur akan dikurangi, jika ada beberapa program pembangunan dikurangi pasti mengakibatkan perlambatan pembangunan.

Jika pembangunan melambat akan mengakibatkan dukungan kepada para pengusaha untukmembangun usahanya akan terhambat pula. Apakah dengan kecilnya pertambahan penerimaan pajak dari tahun ke tahun harus ditambal dengan berhutang? Sebaiknya jangan, karena hutang pasti membayar bunga. Untuk hal tersebut Pemerintah berupaya dengan menerbitkan berbagai kebijakan perpajakan agar penerimaan pajak terus meningkat dengan baik, sehingga pembangunan baik dibidang ekonomi, sosial dan budaya juga terus dapat ditingkatkan. Secara garis besar maka pajak yang dipungut oleh Kantor Pusat Direktorat Jenderal Pajak di Jakarta yang dikenal dengan nama Pajak Pusat adalah Pajak Penghasilan (PPh), Pajak pertambahan Nilai (PPN) dan Pajak Penjualan atas Barang Mewah (PPnBM).

Berbagai kebijaksanaan telah dilakukan oleh Pemerintah untuk senantiasa meningkatkan penerimaan pajak antara lain kebijakan ekstensifikasi dan intensifikasi.
Berdasarkan Peraturan Direktur Jenderal Pajak Nomor PER-35/PJ/2013 bahwa Ekstensifikasi adalah upaya proaktif yang dilakukan oleh Direktorat Jenderal Pajak dalam rangka pemberian Nomor Pokok Wajib Pajak dan/atau pengukuhan Pengusaha Kena Pajak. Ini berarti bahwa Pemerintah mengharapkan seluruh masyarakat Indonesia yang telah memnuhi syarat untuk menjadi Wajib Pajak agar dengan sukarela mendaftrakan diri menjadi Wajib Pajak dan membayar Pajak sesuai Undang-Undang yang berlaku, juga Pemerintah akan secara aktif melakukan pengamatan terhadap data atau fakta yang menunjukkan bahwa para pengusaha yang telah memenuhi syarat menjadi wajib pajak namun belum ada kesadaran sendiri untuk mendaftarkan diri sebagai wajib pajak akan dikukuhkan sebagai wajib pajak melalui pemeriksaan yang dikenal dengan nama pemeriksaan secara jabatan. Dengan demikian jumlah wajib pajak akan bertambah sehingga pembayaran pajak dari wajib pajak yang bertambah tersebut tentunya akan bertambah pula.

Sedangkan berdasarkan Surat Edaran Direktur Jenderal Pajak Nomor SE-69/ PJ/2011 bahwa Intensifikasi adalah upaya penggalian potensi pajak terhadap Wajib Pajak yang sudah terdaftar pada Master File Wajib Pajak. Terhadap Wajib Pajak yang telah terdaftar pada Master File di Direktorat Jenderal Pajak dilakukan pengawasan artinya dengan data yang dipunyai oleh Direktorat Jenderal Pajak akan dilakukan pencocokan dengan data yang dilaporkan oleh Wajib Pajak, apabila ternyata ada ketidaksamaan seperti misalnya Wajib Pajak dalam Surat Pemberitahuan PPh nya melaporkan bahwa peredaran bruto usaha dalam satu tahun sebesar Rp. 1 Miliar, namun data yang dipunyai ol;eh Direktorat Jenderal Pajak sebesar Rp.1,6 Miliar, maka akan dilakukakan pemeriksaan terhadap Wajib Pajak tersebut karaena adanya selisih peredaran bruto sebesar Rp.600 juta tersebut. 
Dari pemeriksaan tersebut diharapkan adanya penambahan pajak sesuai aturan yang berlaku yang akan meningkatkan penerimaan negara. Seperti baru-baru ini Pemerintah menerbitkan kebijakan berupa Pengampunan Pajak yang dikenal dengan Amnesti Pajak yang diatur dalam Undang-Undang Nomor 11 tahun 2016 dimana tujuan utama dari Pengampunan Pajak adalah meminta kepada masyarakat Indonesia untuk jujur dalam membayar pajak, melaporkan seluruh hartanya tanpa ada yang disembunyikan baik harta yang di Dalam Negeri maupun yang ada di Luar Negeri dengan membayar uang tebusan. Setelah pengakuan tersebut dideklarasikan dalam surat pernyataan, maka selanjutnya diajak semua komponen untuk membangun bangsa dengan membayar pajak secara benar sehingga "tidak ada dusta diantara kita".

Demikian juga kebijakan yang akan penulis bahas adalah diterbitkannya Peraturan Pemerintah Nomor 46 tahun 2013 yang ditetapkan oleh Presiden pada tanggal 12 Juni 2013 dan diundangkan pada tanggal 13 Juni 2013 dan mulai diberlakukan pada tanggal 1 Juli 2013 dimana diatur tentang penghitungan pajak penghasilan bagi wajib pajak dengan peredaran jumlah tertentu dalam hal ini peredaran bruto usaha sampai dengan Rp.4.800.000.000,- (empat miliar delapan ratus juta rupiah).

Dalam Peraturan Pemerintah Nomor 46 tahun 2013 dalam pertimbangannya menyatakan bahwa Peraturan Pemerintah Nomor 46 tahun 2013 diundangkan untuk memberikan kemudahan kepada Wajib Pajak orang pribadi dan badan yang memiliki peredaran bruto tertentu, perlu memberikan perlakuan tersendiri dalam hal ketentuan mengenai penghitungan, penyetoran, dan pelaporan Pajak Penghasilan yang terutang.

Dari batasan jumlah peredaran bruto usaha tersebut maka dapat disimpulkan bahwa Peraturan Pemerintah Nomor 46 tahun 2013 tersebut diperuntukkan bagi pengusaha yang masuk dalam katagori Usaha Mikro Kecil dan Menengah (UMKM). Seperti yang diatur dalam Undang-undang Nomor 20 tahun 2008 pada pasal 6 disebutkan bahwa pengusaha yang mempunyai jumlah penjualan sampai de-ngan Rp.50.000.000.000,00 (lima puluh miliar rupiah) dengan jumlah harta tidak lebih dari Rp.10.000.000.000,00 (sepuluh miliar rupiah) disebut pengusaha UMKM. Adapun Pajak Penghasilan yang dikenakan kepada Usaha Mikro Kecil dan Menengah (UMKM) berdasarkan Peraturan Pemerintah Nomor 46 tahun 2013 dengan batasan peredaran bruto usaha sebesar sampai de-ngan Rp.4.800.000.000,00 (empat miliar delapan ratus juta rupiah) adalah sebesar 1\% (satu persen) dari jumlah peredaran bruto usaha dan bersifat final. Peredaran Bruto Usaha diartikan sebagai penghasilan kotor yang belum dikurangi dengan biaya usaha.

\section{Kerangka Teoritik}

\section{Pajak}

Banyak teori-teori tentang pajak, namun Negara telah menetapkan definisi Pajak dalam Undang-Undang Nomor 6 tahun 1983 sebagaimana telah diubah dengan UndangUndang Nomor 16 tahun 2009 tentang Ketentuan Umum dan Tata Cara Perpajakan dalam Pasal 1 angka 1:

Pajak adalah kontribusi wajib kepada
negara yang terutang oleh orang
pribadi atau badan yang bersifat
memaksa berdasarkan undang-
undang, dengan tidak mendapatkan
imbalan secara langsung dan di-
gunakan untuk keperluan negara
bagi sebesar-besarnya kemakmuran
rakyat.

Undang-undang adalah aturan didalam Negara yang harus dipatuhi, maka dari itu agar tidak terjadi penafsiran yang salah, penulis hanya akan membahas tentang Pajak atas dasar definisi dari Undang-undang. Jika 
kita lihat unsur -unsur yang terkandung dalam definisi Pajak tersebut, Diaz Priantara dalam bukunya "Perpajakan Indonesia" edisi 3 (2016:3) lebih lanjut menulis:

Menurut Safri Nurmantu (2003) beberapa unsur pajak adalah:

\section{Iuran atau pungutan}

Dilihat dari segi arah dana pajak, jika arah datangnya pajak berasal dari wajib pajak, maka pajak disebut iuran sedangkan jika arah datangnya kegiatan untuk mewujudkan pajak tersebut berasal dari Pemerintah, maka pajak itu disebut sebagai pungutan.

2. Pajak dipungut berdasarkan undangundang

Salah satu karakter pokok dari pajak adalah bahwa pemungutannya harus berdasarkan undang-undang. Hal ini disebabkan karena pada hakekatnya pajak adalah beban yang harus dipikul oleh rakyat banyak, sehingga dalam perumusan macam, jenis dan berat ringannya tarif pajak, rakyat harus ikut serta menentukan dan menyetujuinya melalui wakil-wakilnya di DPR.

3. Pajak dapat dipaksakan

Fiskus mendapat wewenang dari undang-undang untuk memaksa Wajib Pajak supaya mematuhi melaksanakan kewajiban perpajakannya. Wewenang tersebut dapat dilihat dengan adanya ketentuan sanksi-sanksi administratif maupun sanksi pidana fiskal dalam undang-undang perpajakan, khususnya dalam UU KUP.

4. Tidak menerima atau memperoleh kontraprestasi

Ciri khas utama pajak adalah WP adalah yang membayar pajak tidak menerima atau memperoleh jasa timbal atau kontraprestasi dari Pemerintah. Misalnya jika WP membayar PPh, maka fiskus (otoritas pajak) dan Pemerintah tidak akan memberikan apapun kepadanya sebagai jasa timbal. Sistem $\mathrm{PPh}$ di Indonesia berdasarkan UU PPh sama sekali tidak mengenal adanya kontraprestasi. Tetapi jikalau WP membayar bea meterai terhadap tanda terima uang atau kuitansi, maka disini akan terlihat adanya kontraprestasi dimana pihak yang menyimpan kuitansi dapat menggunakan kuitansi tersebut sebagai alat bukti.

5. Untuk membiayai pengeluaran umum Pemerintah

Pajak dipergunakan untuk membiayai pengeluaran umum Pemerintah dalam menjalankan pemerintahan. Dana yang diterima dari pemungutan pajak dalam pengertian definisi di atas tidak pernah ditujukan untuk sesuatu pengeluaran khusus. Misalnya,Pemerintahmenyatakan bahwa pungutan PPh di Daerah Tingkat II Bojonegoro akan dipergunakan khusus untuk membantu para para arkeolog untuk mempelajari prasasti-prasasti tentang perpajakan di zaman Majapahit. Namun demikian, dalam praktek, banyak dijumpai "pajak" yang hasilnya untuk keperluan khusus, misalnya hydrocarbon tax di negara Eropa, adalah pungutan yang hasil pemungutannya ditujukan khusus untuk mencegah dan atau menanggulangi polusi akibat pencemaran udara oleh hidrokarbon yang berasal dari pemakaian minyak bumi. Contoh lain, adalah motor vehicle tax yaitu pungutan yang hasil pungutannya dipergunakan untuk pemeliharaan jalan. Pajak yang penggunaannya untuk keperluan khusus demikian ini disebut earmarked tax.

Dari definisi Pajak menurut Undangundang dan uraian tentang unsur-unsur pajak diatas memberikan pemahaman kepada kita bahwa Undang-undang mewajibkan peran masyarakat dalam pemenuhan kewajiban di bidang perpajakan perlu terus ditingkatkan dengan mendorong kesadaran, 
pemahaman, dan penghayatan bahwa pajak adalah sumber utama pembiayaan negara dan pembangunan nasional serta merupakan salah satu kewajiban kenegaraan sehingga setiap anggota masyarakat wajib berperan aktif dalam melaksanakan sendiri kewajiban perpajakannya. Adapun jenis pajak di Indonesia antara lain adalah:

a. yang dikelola oleh Pemerintah Pusat:

1) Pajak Penghasilan (PPh);

2) Pajak Pertambahan Nilai (PPN);

3) Pajak Bumi dan Bangunan (PBB) untuk Pertambangan, Perkebunan dan Perhutanan;

4) Bea Meterai.

b. sedangkan yang dikelola oleh Pemerintah Daerah, antara lain adalah:

1) Pajak Bumi dan Bangunan (PBB) untuk perumahan perkotaan dan perdesaan;

2) Bea Perolehan Hak atas Tanah dan Bangunan (BPHTB);

3) Pajak Hotel dan Restoran;

4) Pajak Kendaraan Bermotor (PKB);

5) Pajak Reklame;

6) Pajak Hiburan.

Setelah kita mengetahui bahwa pajak itu dapat dipaksakan dan harus dipungut secara adil, tetapi masyarakat tidak mendapat imbalan secara langsung, maka timbul pertanyaan, apa yang didapat oleh masyarakat akibat pemungutan pajak tersebut? Irianto dalam bukunya"Pajak Negara dan Demokrasi" (2009:68) menjelaskan; Selain itu, pemerintah juga dapat mengalokasikan uang pajak untuk kepentingan publik yang terdiri dari (1) standar pelayanan umum minimum, khususnya dalam bidang pendidikan, kesehatan, infrastruktur jalan, dan irigasi; (2) pelayanan umum yang menghasilkan manfaat bagi penduduk dan/atau daerah lain; (3) pelayanan umum sebagai akibat dari aktivitas pendidikan dan/atau daerah lain; (4) pengentasan kemiskinan; (5) pemberantasan penyakit menular; (6) penyiapan sarana dan pra- sarana di kawasan transmigrasi; (7) penyiapan sarana dan prasarana di kawasan transmigrasi, terisolasi, terpencil, dan daerah perbatasan dengan negara lain; (8) pelestarian lingkungan hidup; (9) pelaksanaan kegiatan rehabilitasi hutan dan lahan kritis (earmarked \{peruntukan\} dana reboisasi); (10) kegiatan peningkatan kinerja pajak dan retribusi daerah dan/ atau peningkatan efisiensi dan efektivitas pengelolaan pengeluaran daerah (Final Report, 2003:384).

Dari pendapat tersebut dapat ditarik kesimpulan bahwa sebetulnya hasil pungutan pajak tersebut akan kembali ke masyarakat secara umum dalam bentuk dukunganmenyeluruh baikuntukkeamanan, kemajuan daerah tertinggal, menunjang untuk memajukan usaha, dan lain-lain yang pada akhirnya demi kesejahteraan rakyat Indonesia. Selanjutnya siapa yang menanggung beban pajak tersebut, Erly Suandy dalam bukunya "Hukum Pajak" (2011:43) menyatakan: Secara garis besar subyek pajak adalah pihak-pihak (orang maupun badan) yang akan dikenakan pajak, sedangkan obyek pajak adalah segala sesuatu yang akan dikenakan pajak. Wajib Pajak adalah subyek pajak yang telah memenuhi syarat-syarat obyektif sehingga kepadanya diwajibkan pajak. Dengan perkataan lain, setiap Wajib Pajak adalah subyek pajak.

\section{Penghasilan}

Penulis akan membahas masalah Peraturan Pemerintah Nomor 46 tahun 2013 sehingga pembahasan hanya akan terkait tentang Pajak Penghasilan. Seperti telah diatur dalam Undang-undang Nomor 7 tahun 1983 sebagaimana telah diubah dengan Undang-undang Nomor 36 tahun 2008 tentang Pajak Penghasilan pada pasal 4 ayat (1): Yang menjadi obyek pajak adalah penghasilan yaitu setiap tambahan kemampuan ekonomis yang diterima atau diperoleh Wajib Pajak, baik yang berasal dari Indonesia maupun dari luar Indonesia 
yang dapat dipakai untuk konsumsi atau untuk menambah kekayaan Wajib Pajak yang bersangkutan dengan nama 'dan dalam bentuk apapun.

Lebih lanjut Undang-undang Nomor 7 tahun 1983 sebagaimana telah diubah dengan Undang-undang Nomor 36 tahun 2008 pasal 4 ayat (1) di penjelasan menerangkan sebagai berikut :

Undang-undang ini menganut prinsip pemajakan atas penghasilan dalam pengertian yang luas, yaitu bahwa pajak dikenakan atas tambahan kemampuan ekonomis yang diterima atau diperoleh Wajib Pajak dari manapun asalnya yang dapat dipergunakan untuk konsumsi atau menambah kekayaan Wajib Pajak tersebut. Pengertian penghasilan dalam Undang-undang ini tidak memperhatikan adanya penghasilan dari sumber tertentu, tetapi pada adanya tambahan kemampuan ekonomis. Tambahan kemampuan ekonomis yang diterima atau diperoleh Wajib Pajak merupakan ukuran terbaik mengenai kemampuan Wajib Pajak tersebut untuk ikut bersama-sama memikul biaya yang diperlukan pemerintah untuk kegiatan rutin dan pembangunan. Dilihat dari mengalirnya tambahan kemampuan ekonomis kepada Wajib Pajak, maka penghasilan dapat dikelompokkan menjadi:

1. penghasilan dari pekerjaan dalam hubungan kerja dan pekerjaan bebas seperti gaji, honorarium, penghasilan dari praktek dokter, notaris, aktuaris, akuntan, pengacara, dan sebagainya;

2. penghasilan dari usaha dan kegiatan;

3. penghasilan dari modal, yang berupa harta gerak ataupun harta tak gerak, seperti bunga, dividen, royalti, sewa, dan keuntungan penjualan harta atau hak yang tidak dipergunakan untuk usaha; dan

4. penghasilanlain-lain, sepertipembebasan utang dan hadiah.

Dilihat dari penggunaannya, penghasilan dapat dipakai untuk konsumsi dan dapat pula ditabung untuk menambah kekayaan Wajib Pajak. Karena Undang-undang ini menganut pengertian penghasilan yang luas maka semua jenis penghasilan yang diterima atau diperoleh dalam suatu tahun pajak digabungkan untuk mendapatkan dasar pengenaan pajak. Dengan demikian, apabila dalam satu tahun pajak suatu usaha atau kegiatan menderita kerugian, kerugian tersebut dikompensasikan dengan penghasilan lainnya (kompensasi horizontal) pada tahun berikutnya, kecuali kerugian yang diderita diluar negeri. Namun demikian, apabila suatu jenis penghasilan dikenai pajak dengan tarif yang bersifat final atau dikecualikan dari obyek pajak, maka penghasilan tersebut tidak boleh digabungkan dengan penghasilan lainnya yang dikenai tarif umum.

Dari penjelasan Undang-undang ini berarti pengenaan pajak penghasilan ada yang dikenai tarif umum dan ada yang dikenai tarif final.

\section{Pajak Penghasilan}

Menurut Siti Resmi dalam bukunya "Perpajakan: Teori dan Kasus" (2016:143), Pajak Penghasilan (PPh) dapat dikelompokkan menjadi PPh yang bersifat Final dan PPh bersifat tidak final. Pajak Penghasilan bersifat final artinya pajak penghasilan yang pengenaannya sudah final (berakhir) dari total pajak penghasilan terutang pada akhir tahun pajak. Pajak penghasilan bersifat final dikelompokkan sebagai berikut:

1. PPh atas penghasilan dari usaha yang diterima/diperoleh Wajib Pajak yang memiliki peredaran bruto tertentu;

2. PPh pasal 15 UU PPh untuk usaha tertentu;

3. PPh pasal 4 ayat (2) UU PPh.

Terhadap pengelompokan penghasilan yang dikenai Pajak Penghasilan dengan tarif umum dan Pajak Penghasilan dengan tarif Final dapat diuraikan sebagai berikut: 
1. Jenis Penghasilan yang Dikenai Pajak Penghasilan dengan Tarif Umum

Tentang Jenis penghasilan yang dikenai Pajak Penghasilan dengan Tarif Umum diatur dalam Pasal 4 ayat (1) Undang Undang Pajak Penghasilan: Yang menjadi obyek pajak adalah penghasilan yaitu setiap tambahan kemampuan ekonomis yang diterima atau diperoleh Wajib Pajak, baik yang berasal dari Indonesia maupun dari Luar Indonesia, yang dapat dipakai untuk konsumsi atau untuk menambah kekayaan Wajib Pajak yang bersangkutan, dengan nama dan dalam bentuk apapun, termasuk:

a. penggantian atau imbalan berkenaan dengan pekerjaan atau jasa yang diterima atau diperoleh termasuk gaji, upah, tunjangan, honorarium, komisi, bonus, gratifikasi, uang pensiun, atau, imbalan dalam bentuk lainnya, kecuali ditentukan lain dalam Undang-undang ini;

b. hadiah dari undian atau pekerjaan atau kegiatan, dan penghargaan;

c. laba usaha;

d. keuntungan karena penjualan atau karena pengalihan harta

e. penerimaan kembali pembayaran pajak yang telah dibebankan sebagai biaya dan pembayaran tambahan pengembalian pajak;

f. bunga termasuk premium, diskonto, dan imbalan karena jaminan pengembalian utang;

g. dividen, dengan nama dan dalam bentuk apapun, termasuk dividen dari perusahaan asuransi kepada pemegang polis, dan pembagian sisa hasil usaha koperasi;

h. royalti atau imbalan atas penggunaan hak;

i. sewa dan penghasilan lain sehubungan dengan penggunaan harta;

j. penerimaan atau perolehan pembayaran berkala;

k. keuntungan karena pembebasan utang, kecuali sampai dengan jumlah tertentu yang ditetapkan dengan Peraturan Pe- merintah;

l. keuntungan selisih kurs mata uang asing;

m. selisih lebih karena penilaian kembali aktiva;

n. premi asuransi;

o. iuran yang diterima atau diperoleh perkumpulan dari anggotanya yang terdiri dari Wajib Pajakyang menjalankan usaha atau pekerjaan bebas;

p. tambahan kekayaan neto yang berasal dari penghasilan yang belum dikenakan pajak;

q. penghasilan dari usaha berbasis syariah;

r. imbalan bunga sebagaimana dimaksud dalam Undang-undang yang mengatur mengenai ketentuan umum dan tata cara perpajakan; dan

s. surplus Bank Indonesia.

2. Jenis Penghasilan yang Dikenai Pajak Bersifat Final

Mengenai jenis penghasilan yang dikenai Pajak Final diatur dalam Pasal 4 ayat (2) UU PPh sebagai berikut: Penghasilan di bawah ini dapat dikenai pajak bersifat final:

a. penghasilan berupa bunga deposito dan tabungan lainnya, bunga obligasi dan surat utang negara, dan bunga simpanan yang dibayarkan oleh koperasi kepada anggota koperasi orang pribadi;

b. penghasilan berupa hadiah undian;

c. penghasilan dari transaksi saham dan sekuritas lainnya, transaksi derivatif yang diperdagangkan di bursa, dan transaksi penjualan saham atau pengalihan penyertaan modal padaperusahaan pasangannya yang diterima oleh perusahaan modal ventura;

d. penghasilan dari transaksi pengalihan harta berupa tanah dan/atau bangunan, usaha jasa konstruksi, usaha real estate, dan persewaan tanah dan/atau bangunan, dan

e. penghasilan tertentu lainnya, yang diatur dengan atau berdasarkan Peraturan Pemerintah. 
Atas dasar Pasal 4 ayat (2) huruf e inilah maka ditetapkanlah Peraturan Pemerintah Nomor 46 tahun 2013 yang mengatur bahwa penghasilan dari usaha yang diterima atau diperoleh Wajib Pajak yang memiliki peredaran bruto tertentu dikenai pajak penghasilan yang bersifat final.

\section{Penghasilan Kena Pajak dan Tarif Pajak} Penghasilan

Sebagaimana telah diuraikan di atas bahwa wajib pajak terdiri atas wajib pajak badan dan wajib pajak orang pribadi, maka dalam penghitungan pajak penghasilan terdapat juga Tarif pajak penghasilan untuk wajib pajak badan dan tarif pajak penghasilan untuk wajib pajak orang pribadi.

Sebelum membahas tentang tarif, maka terlebih dahulu penulis akan membahas tentang bagaimana menghitung penghasilan neto usaha atau pekerjaan bebas sebagai dasar untuk menghitung Pajak Penghasilan. Ketentuan tersebut disebutkan dalam Pasal 14 ayat (1) dan (2) UU Pajak Penghasilan:

(1) Norma Penghitungan Penghasilan Neto untuk menentukan penghasilan neto, dibuat dan disempurnakan terusmenerus serta diterbitkan oleh Direktur Jenderal Pajak;

(2) Wajib Pajak orang pribadi yang melakukan kegiatan usaha atau pekerjaan bebas yang peredaran brutonya dalam 1 (satu) tahun kurang dari Rp.4.800.000.000,00 (empat miliar delapan ratus juta rupiah) boleh menghitung penghasilan neto dengan menggunakan Norma Penghitungan Penghasilan Neto sebagaimana dimaksud pada ayat (1), dengan syarat memberitahukan kepada Direktur Jenderal Pajak dalam jangka waktu 3 (tiga) bulan pertama dari tahun pajak yang bersangkutan.

Dijelaskan dalam penjelasan Pasal 14 ayat (1) dan (2) diatas sebagai berikut: untuk memberikan kemudahan dalam menghitung besarnya penghasilan neto bagi Wajib Pajak orang pribadi yang menjalankan usaha atau pekerjaan bebas dengan peredaran bruto tertentu, Direktur Jenderal Pajak menerbitkan norma penghitungan. Norma Penghitungan adalah pedoman untuk menentukan besarnya penghasilan Neto yang diterbitkan oleh Direktur Jenderal Pajak dan disempurnakan terus menerus.

Penggunaan Norma Penghitungan tersebut pada dasarnya dilakukan dalam halhal:

a. tidak terdapat dasar penghitungan yang lebih baik, yaitu pembukuan yang lengkap; atau

b. pembukuan atau catatan peredaran bruto Wajib Pajak ternyata diselenggarakan secara tidak benar.

Norma Penghitungan disusun sedemikian rupa berdasarkan hasil penelitian atau data lain, dan dengan memperhatikan kewajaran. Norma Penghitungan akan sangat membantu Wajib Pajak yang belum mampu menyelenggarakan pembukuan untuk menghitung penghasilan neto.

Misal dalam Norma Penghitungan Penghasilan Neto yang terakhir ditetapkan dengan Peraturan Direktur Jenderal Pajak Nomor 17/Pj/2015 tanggal 10 April 2015 disebutkan bahwa UsahaWP termasukdalam daftar norma 25\%, maka untuk menghitung penghasilan neto adalah Peredaran bruto usaha/penerimaan kotor dikalikan $25 \%$.

Bagaimana dengan Wajib Pajak badan? Karena penggunaan norma penghitungan penghasilan neto hanya diperkenankan untuk wajib pajak orang pribadi, maka untuk menghitung penghasilan neto wajib pajak badan adalah sesuai pembukuan yaitu Peredaran Bruto Usaha dikurangi Harga Pokok Penjualan dan Biaya/Beban usaha

Jadi dapat disimpulkan bahwa untuk menghitung Penghasilan Neto:

a. Untuk Wajib Pajak Badan harus menggunakan pembukuan

b. Untuk Wajib Pajak Orang Pribadi:

1). Dapat menyelenggarakan pembukuan 
2). Dapat menggunakan Norma Penghitungan Penghasilan Neto (untuk peredaran bruto usaha kurang dari Rp.4,8 Miliar) .

Berdasarkan ketentuan Pasal 17 ayat (1) Undang-undang Pajak Penghasilan:

Contoh 1:

Sebagai contoh perhitungan Pajak Terutang adalah sebagai berikut:

WP Orang Pribadi Status Kawin anak 1 (K/1)

Peredaran Bruto Usaha WP Orang Pribadi th.2016: Rp.400.000.000,00

Norma Penghitungan Penghasilan Neto (15\%).........Rp. 60.000.000,00

Penghasilan Tidak Kena Pajak (PTKP):

$$
\begin{aligned}
\text { WP sendiri } & =\text { Rp. } 54 \cdot 000 \cdot 000,00 \\
\text { Status kawin } & =\text { Rp. } 4.500 .000,00 \\
\text { Tanggungan } & =\text { Rp. } 4.500 .000,00 \\
& \text { Rp. } 63.000 .000,00(-)
\end{aligned}
$$

Penghasilan Kena Pajak. Nihil

Pajak Terutang. Nihil

Artinya karena Penghasilan Tidak Kena Pajak lebih besar dari Penghasilan Kena Pajak, maka Tidak ada Pajak yang masih harus dibayar oleh Wajib Pajak alias NIHIL

\section{Peraturan Pemerintah (PP) Nomor 46 Tahun 2013}

Pada tanggal 13 Juni 2013 diundangkanlah Peraturan Pemerintah Nomor 46 tahun 2013 tentang Pajak Penghasilan atas Penghasilan dari usaha yang diterima atau diperoleh wajib pajak yang memiliki peredaran bruto tertentu.

Dalam pertimbangannya Peraturan Pemerintah tersebut menyatakan bahwa dikeluarkannya Peraturan Pemerintah Nomor 46 tahun 2013 adalah untuk memberikan kemudahan kepada Wajib Pajak orang pribadi dan badan yang memiliki peredaran bruto tertentu, penyetoran, dan pelaporan Pajak Penghasilan yang terutang. Sebagai aturan pelaksanaan Peraturan Pemerintah Nomor 46 tahun 2013 ini, setelah diundangkannya Peraturan Pemerintah ini diterbitkan juga Peraturan Menteri Keuangan Republik Indonesia Nomor.107/ PMK.011/2013 tanggal 6 Agustus 2013 dan Surat Edaran Direktur Jenderal Pajak Nomor: SE-42/PJ/2013 tanggal 2 September 2013. Aturan aturan pelaksanaan tersebut adalah untuk menjelaskan tentang segala sesuatu yang mungkin belum diuraikan secara detil di Peraturan Pemerintah Nomor 46 tahun 2013 sehingga diharapkan tidak terjadi kesalahan dalam penerapannya.

Dalam Pasal 2 Peraturan Pemerintah Nomor 46 tahun 2013 pada ayat (1), (2), (3) dan (4) diatur sebagai berikut:

(1) Atas penghasilan dari usaha yang diterima atau diperoleh Wajib Pajak yang memiliki peredaran bruto tertentu, dikenai Pajak Penghasilan yang bersifat final.

(2) Wajib Pajak yang memiliki peredaran bruto tertentu sebagaimana dimaksud pada ayat (1) adalah Wajib Pajak yang memenuhi kriteria sebagai berikut:

a. Wajib Pajak orang pribadi atau Wajib Pajak badan tidak termasuk bentuk usaha tetap; dan

b. Menerima penghasilan dari usaha, tidak termasuk penghasilan dari jasa sehubungan dengan pekerjaan bebas, dengan peredaran bruto tidak melebihi Rp.4.800.000.000,00 (empat miliar delapan ratus juta rupiah) dalam 1 (satu) tahun pajak.

(3) Tidak termasuk Wajib Pajak orang pribadi sebagaimana dimaksud pada ayat (2) adalah Wajib Pajak orang pribadi yang melakukan kegiatan usaha perdagangan dan/atau jasa yang dalam usahanya:

a. menggunakan sarana atau prasarana yang dapat dibongkar pasang, baik 
yang menetap maupun yang tidak menetap; dan

b. menggunakan sebagian atau seluruh tempat untuk kepentingan umum yang tidak diperuntukkan bagi tempat usaha atau berjualan

(4) Tidak termasuk Wajib Pajak badan sebagaimana dimaksud pada ayat (2) adalah:

a. Wajib Pajak badan yang belum beroperasi secara komersial; atau

b. Wajib Pajak badan yang dalam jangka waktu 1 (satu) tahun setelah beroperasi secara komersial memperoleh peredaran bruto melebihi Rp.4.800.000.000,00 (empat miliar delapan ratus juta rupiah)

Selanjutnya Pasal 3 ayat (1), (2), (3) dan (4) Peraturan Pemerintah No.46 Tahun 2013 menyatakan:

(1) Besarnya tarif Pajak Penghasilan yang bersifat final sebagaimana dimaksud dalam Pasal 2 adalah 1\% ( satu persen)

(2) Pengenaan Pajak Penghasilan sebagaimana dimaksud pada ayat (1) didasarkan pada peredaran bruto dari usaha dalam 1 (satu) tahun dari Tahun Pajak terakhir sebelum Tahun Pajak yang bersangkutan.

(3) Dalam hal peredaran bruto kumulatif Wajib Pajak pada suatu bulan telah melebihi jumlah Rp.4.800.000.000,00 (empat miliar delapan ratus juta rupiah) dalam suatu Tahun Pajak, Wajib Pajak tetap dikenai tarif Pajak Penghasilan yang telah ditentukan berdasarkan ketentuan sebagaimana dimaksud pada ayat (1) sampai dengan akhir Tahun Pajak yang bersangkutan.

(4) Dalam hal peredaran bruto Wajib Pajak telah melebihi jumlah Rp.4.800.000.000,00 (empat miliar delapan ratus juta rupiah) pada akhir Tahun Pajak, atas penghasilan yang diterima atau diperoleh Wajib Pajak pada Tahun Pajak berikutnya dikenai tarif Pajak Penghasilan berdasarkan ketentuan Undang-Undang Pajak Penghasilan.

Dari ketentuan Pasal 2 dan Pasal 3 Peraturan Pemerintah Nomor 46 tahun 2013 tersebut diatas dapat ditarik kesimpulan sebagai berikut:

a). Untuk Wajib Pajak Orang Pribadi maupun Badan yang mempunyai penghasilan dari usaha (misal toko, pabrik), tidak termasuk pekerjaan bebas (missal dokter, konsultan) yang mempunyai peredaran bruto usaha dalam satu tahun pajak dengan jumlah yang tidak melebihi Rp.4.800.000.000,00 (empat miliar delapan ratus juta rupiah) dikenakan Pajak berdasarkan Peraturan Pemerintah Nomor 46 tahun 2013 dengan tarif sebesar $1 \%$.

b). Dasar pengenaan pajak yang digunakan untuk menghitung Pajak Penghasilan tersebut di point a diatas, dan bersifat final sebagaimana dimaksud dalam Pasal 2 ayat (1) adalah jumlah peredaran bruto setiap bulan.

c). Dengan demikian penghitungan penghasilan neto untuk menghitung pajak atas penghasilan dari usaha yang mempunyai peredaran bruto tidak melebihi Rp.4.800.000.000,00 (empat miliar delapan ratus juta rupaiah) dalam 1 (satu) tahun pajak dengan menggunakan tarif PPh Umum, tidak diperlukan.

Lebih lanjut wajib pajak yang termasuk dalam kelompok pekerjaan bebas yaitu kelompok yang tidak dikenai penghitungan Pajak sesuai PP 46 disebutkan dalam Penjelasan Pasal 2 ayat (2) PP 46, bahwa jasa sehubungan dengan pekerjaan bebas meliputi:

a. tenaga ahli yang melakukan pekerjaan bebas, yang terdiri dari pengacara, akun- 
tan, arsitek, dokter, konsultan, notaris, penilai, dan aktuaris;

b. pemain musik, pembawa acara, penyanyi, pelawak, bintang film, bintang sinetron, bintang iklan, sutradara, kru film, foto model, peragawan/peragawati, pemain drama, dan penari;

c. olahragawan;

d. penasihat, pengajar, pelatih, penceramah, penyuluh, dan moderator;

e. pengarang, peneliti, dan penterjemah;

f. agen iklan;

g. pengawas atau pengelola proyek;

h. perantara;

i. petugas penjaja barang dagangan;

j. agen asuransi; dan

k. distributor perusahaan pemasaran berjenjang (multilevel marketing ) atau penjualan langsung (direct selling) dan kegiatan sejenis lainnya.

Artinya bahwa untuk pekerjaan bebas tersebut tidak dikenakan penghitungan pajak berdasarkan PP 46 th. 2013 .

Dengan dikeluarkannya Peraturan Pemerintah No.46 tahun 2013 ini, menguntungkan atau merugikan bagi Wajib Pajak? Analisis terhadap hal tersebut hanya dapat dilakukan untuk Wajib Pajak Badan, karena Wajib Pajak Badan tidak ada faktor pengurang dari penghasilan neto usaha sedangkan Wajib Pajak Orang Pribadi mempunyai faktor pengurang yang berbeda-beda jumlahnya menurut tanggungan keluarga.Untuk kajian hal itu marilah kita lihat pada tabel 1. Perbandingan PPh menurut PP 46 dan PPh Umum terhadap WP Badan.
Dari penghitungan dalam tabel 1 . Perbandingan PPh menurut PP 46 dan PPh Umum terhadap WP Badan tersebut dapat disimpulkan bahwa:

a. Jika secara Riil Laba Neto usaha sebesar 10\% dari Peredaran Bruto, maka penghitungan memakai PP 46 akan menguntungkan, karena dengan PPh Umum seharusnya membayar Rp.7.500.000,tetapi dengan PP 46 hanya membayar PPh sebesar Rp.6.000.000,-

b. Jika secara Riil Laba Neto usaha sebesar 8\% dari Peredaran Bruto, maka penghitungan dengan memakai PP 46 akan sama dengan penghitungan memakai PPh Umum.

c. Jika secara Riil Laba Neto usaha sebesar 7\% dari Peredaran Bruto, maka penghitungan memakai PP 46 akan merugikan wajib pajak, karena seharusnya membayar Rp.5.250.000,- namun dengan PP 46 harus membayar Rp.6.000.000,-

\section{Hasil Penelitian dan Pembahasan}

Berdasarkan analisis atas pelaksanaan Peraturan Pemerintah Nomor 46 tahun 2013 yang pengenaan Pajak penghasilan adalah 1\% dari Peredaran Bruto Usaha, dan penghitungan Pajak Penghasilan berdasarkanUndang-undang PajakPeng-hasilan dimana Pajak Penghasilan didasarkan pada Penghasilan Neto Usaha, bahkan untuk Wajib Pajak Orang Pribadi masih harus dikurangi dengan Penghasilan Tidak Kena

Tabel 1. Perbandingan PPh menurut PP 46 dan PPh Umum terhadap WP Badan

\begin{tabular}{|l|l|l|l|l|l|}
\hline No. & $\begin{array}{c}\text { Peredaran Bruto } \\
\text { setahun (Rp) }\end{array}$ & $\begin{array}{c}\text { Laba Neto } \\
(\%)\end{array}$ & Laba neto (Rp) & \multicolumn{2}{|c|}{ Pajak Penghasilan } \\
\hline & & & & PP 46 (1\%) & $\begin{array}{l}\text { PPh Umum } \\
(12,5 \%)\end{array}$ \\
\hline 1 & 600.000 .000 & 10 & 60.000 .000 & 6.000 .000 & 7.500 .000 \\
\hline 2 & 600.000 .000 & 8 & 48.000 .000 & 6.000 .000 & 6.000 .000 \\
\hline 3 & 600.000 .000 & 7 & 42.000 .000 & 6.000 .000 & 5.250 .000 \\
\hline
\end{tabular}


Pajak, maka dapat dianalisis beberapa hal sebagai berikut:

1. Jika ada pengusaha yang mempunyai penghasilan Neto dibawah PTKP, menurut PP 46 tetap harus membayar Pajak Penghasilan sebesar 1\% dari Peredaran Bruto usaha, namun menurut Undang-undang Pajak Penghasilan tidak perlu membayar pajak seperti penulis contohkan pada contoh 1 diatas. Bahkan pada Pasal 2 ayat (2) Undang-undang Nomor 7 tahun 1983 sebagaimana telah diubah dengan Undang-undang Nomor 36 tahun 2008, pada penjelasan pasal tersebut dinyatakan bahwa Wajib Pajak OrangPribadiyangmenerimapenghasilan dibawah Penghasilan Tidak Kena Pajak (PTKP) tidak wajib mendaftarkan diri untuk memperoleh NPWP. Disini jelas asas keadilan dari Undang-undang Pajak Penghasilan sangatlah nyata, artinya bagi Wajib Pajak yang masih kecil (penghasilan dibawah PTKP) dilindungi untuk tidak perlu membayar pajak lebih dahulu. Namun kalau dilihat di PP46 semua wajib pajak termasuk yang masih mempunyai penghasilan dibawah PTKP pun harus membayar pajak, bahkan yang rugipun harus membayar pajak, karena pengenaan Pajak Penghasilannya adalah 1\% dari Peredaran bruto Usaha.

2. Untuk mempertahankan tujuan dikeluarkannya Peraturan Pemerintah nomor 46 tahun 2013 yaitu kemudahan bagi Wajib Pajak dan memberikan perlindungan bagi Wajib Pajak yang tergolong kecil antara lain yang kita kenal dengan Usaha Mikro Kecil, maka penulis mengusulkan adanya pengurangan terhadap Peredaran Bruto Usaha sebelum dikenakan Tarif sebesar 1\% dari peredaran Bruto Usaha yaitu sebesar jumlah tertentu. Jumlah tertentu ini dapat ditentukan oleh Direktorat Jenderal Pajak sesuai kajian yang realistis. Namun penulis mengusulkan besaran jumlah tertentu tersebut adalah $10 \mathrm{x}$
Rp.54.000.000,00 = Rp.540.000.000,00. Argumentasi jumlah tersebut adalah bahwa nilai terendah dari PTKP adalah Rp.54.000.000,00 (Tk ), dan asumsi untung bersihadalah $10 \%$.Sehinggauntuk Wajib Pajak yang mempunyai Peredaran Bruto Usaha setahun sampai dengan jumlah Rp.540.000.000,00 (lima ratus empat puluh juta rupiah) tidak dikenakan pajak. Dan misalkan ada Wajib Pajak yang mempunyai Peredaran Bruto Usaha setahun sebesar Rp.1.000.000.000,00 (satu milyar rupiah), berdasarkan PP 46 akan dikenakanPajakpenghasilansebesar 1\% x (Rp.1 M - Rp.540.000.000,00) = 1\% $\mathrm{x}$ Rp.460.000.000,00 = Rp.4.600.000,00 (empat juta enam ratus ribu rupiah), sehingga tidak dikenakan $1 \% \quad \mathrm{x}$ Rp. $1 \mathrm{M}=$ Rp.10 juta untuk aturan PP 46 sekarang ini. Argumentasi usulan penulis untuk besaran pengurang Peredaran Bruto usaha sebelum dikenakan Pajak Penghasilan sesuai PP46 tahun 2013 ini mungkin masih banyak pendapat lain, namun yang penting ada besaran angka pengurang Peredaran Bruto usaha tersebut sebelum dikenakan tarif 1\%. Hal ini semata-mata untuk memberikan rasa keadilan dan perlindungan bagi wajib pajak yang usahanya masih kecil, sehingga terlihat adanya upaya Pemerintah dalam mendorong dan memberi perlindungan untuk kemajuan usaha bagi kelompok Usaha Mikro Kecil dan Menengah tersebut.

\section{Kesimpulan dan Saran}

Sesuai pembahasan diatas dapat disimpulkan:

1. Bahwa untuk alasan kemudahan dalam menghitung Pajak, Peraturan Pemerintah Nomor 46 tahun 2013 masih diperlukan keberadaannya;

2. Bahwa jika terhadap Peredaran Bruto Usaha yang akan dikenakan PPh menurut PP 46 (1\% dari Bruto) tidak dikurangi 
terlebih dahulu dengan sejumlah tertentu, maka Wajib Pajak kecil yang termasuk dalam golongan UMKM akan lebih terbebani oleh pengenaan pajak penghasilan tersebut, padahal seharusnya pengusaha kecil perlu didukung untuk maju.
3. Bahwa sesuai usulan diatas, maka dengan demikian bagi Wajib Pajak Orang Pribadi yang mempunyai Peredaran Bruto Usaha sebesar sampai dengan Rp.540.000.000,00 (lima ratus empat puluh juta rupiah) dalam setahun, tidak dikenakan Pajak Penghasilan.

\section{Daftar Pustaka}

Fitriandi dkk. 2011. Kompilasi Undang-Undang nomor 6 tahun 1983 sebagaimana telah diubah dengan Undang-Undang Nomor 28 tahun 2007. Jakarta: Salemba Empat.

Fitriandi dkk. 2011. Kompilasi Undang-Undang Nomor 7 tahun 1983 sebagaimana telah diubah dengan Undang-undang Nomor 36 tahun 2008. Jakarta: Salemba Empat.

Irianto. 2011. Pajak Negara Demokrasi dan Konsep dan Implementasinya di Indonesia . Yogyakarta: Laksbang Mediatama.

Kementerian Keuangan Republik Indonesia. 2013. Peraturan Menteri Keuangan Republik Indonesia Nomor.107/PMK.011/2013.

Priantara, Diaz. 2016. Perpajakan Indonesia. Jakarta: Mitra Wacana Media.

Republik Indonesia. 2013. "Peraturan Pemerintah Nomor 46 tahun 2013”.

Resmi, Siti. 2016. Perpajakan Teori dan Kasus. Jakarta: Salemba Empat.

Suandy, Erly. 2011. Hukum Pajak. Jakarta: Salemba Empat. 